University of Nebraska - Lincoln

DigitalCommons@University of Nebraska - Lincoln

Faculty Publications: Department of Entomology

$9-2008$

\title{
Temperature affects microbial decomposition of cadavers (Rattus rattus) in contrasting soils
}

David O. Carter

University of Nebraska-Lincoln, dcarter2@unl.edu

David Yellowlees

James Cook University, david.yellowlees@jcu.edu.au

Mark Tibbett

University of Western Australia, Mark.Tibbett@uwa.edu.au

Follow this and additional works at: https://digitalcommons.unl.edu/entomologyfacpub

Part of the Entomology Commons

Carter, David O.; Yellowlees, David; and Tibbett, Mark, "Temperature affects microbial decomposition of cadavers (Rattus rattus) in contrasting soils" (2008). Faculty Publications: Department of Entomology. 188.

https://digitalcommons.unl.edu/entomologyfacpub/188

This Article is brought to you for free and open access by the Entomology, Department of at DigitalCommons@University of Nebraska - Lincoln. It has been accepted for inclusion in Faculty Publications: Department of Entomology by an authorized administrator of DigitalCommons@University of Nebraska - Lincoln. 
Published in Applied Soil Ecology 40:1 (September 2008), pp. 129-137; doi: 10.1016/j.apsoil.2008.03.010 Published by Elsevier B.V. Used by permission. http://www.elsevier.com/locate/apsoil

Submitted October 22, 2007; revised March 20, 2008; accepted March 26, 2008; published online May 19, 2008.

\title{
Temperature affects microbial decomposition of cadavers (Rattus rattus) in contrasting soils
}

\author{
David O. Carter, ${ }^{1}$ David Yellowlees, ${ }^{1}$ and Mark Tibbett ${ }^{2}$ \\ ${ }^{1}$ School of Pharmacy and Molecular Sciences, James Cook University, Douglas, QLD 4811, Australia \\ ${ }^{2}$ Centre for Land Rehabilitation, School of Earth and Geographical Sciences, University of Western Australia, \\ Crawley, WA 6009, Australia
}

Corresponding author - D. O. Carter; present address: Department of Entomology, University of Nebraska-Lincoln, 202 Entomology Hall, Lincoln, NE 68583-0816, USA; tel 402 472-8285, fax 402 472-4687, email dcarter2@unl.edu

\begin{abstract}
The ecology of soils associated with dead mammals (i.e. cadavers) is poorly understood. Although temperature and soil type are well known to influence the decomposition of other organic resource patches, the effect of these variables on the degradation of cadavers in soil has received little experimental investigation. To address this, cadavers of juvenile rats (Rattus rattus) were buried in one of three contrasting soils (Sodosol, Rudosol, and Vertosol) from tropical savanna ecosystems in Queensland, Australia and incubated at $29^{\circ} \mathrm{C}, 22^{\circ} \mathrm{C}$, or $15^{\circ} \mathrm{C}$ in a laboratory setting. Cadavers and soils were destructively sampled at intervals of 7 days over an incubation period of 28 days. Measurements of decomposition included cadaver mass loss, carbon dioxide-carbon $\left(\mathrm{CO}_{2}-\mathrm{C}\right)$ evolution, microbial biomass carbon (MBC), protease activity, phosphodiesterase activity, and soil $\mathrm{pH}$, which were all significantly positively affected by cadaver burial. A temperature effect was observed where peaks or differences in decomposition that at occurred at higher temperature would occur at later sample periods at lower temperature. Soil type also had an important effect on some measured parameters. These findings have important implications for a largely unexplored area of soil ecology and nutrient cycling, which are significant for forensic science, cemetery planning and livestock carcass disposal.
\end{abstract}

Keywords: carcass, protease, phosphodiesterase, carbon dioxide, microbial biomass, $\mathrm{pH}$, forensic taphonomy, gravesoil, $Q_{10}$

\section{Introduction}

The decomposition of dead mammals (i.e. cadavers) in terrestrial ecosystems has received increased attention due to pressing issues in forensic science and public health. An understanding of the fate of cadavers has implications for the estimation of postmortem interval (Vass et al., 1992), location of clandestine gravesites (France et al., 1992) and transmission and degradation of causative agents (Rapp et al., 2006). Although several studies have investigated the fate of the cadaver itself (e.g. Megyesi et al., 2005), few studies have investigated the ecology of soils associated with a cadaver (gravesoils) (e.g. Fiedler et al., 2004; Rapp et al., 2006). As a consequence, the fundamental processes associated with cadaver decomposition in soil remain poorly understood. Prominent among these is the effect of temperature on gravesoil ecology.

It is well understood that temperature can have a significant effect on the decomposition of organic resource patches in soil (Swift et al., 1979), which is primarily due to the effect of temperature on microbial metabolism and abiotic chemical reactions (Paul and Clark, 1996). However, the effect of temperature on cadaver decomposition in soil, although inferred (Morovic-Budak, 1965), has yet to be investigated experimentally. Further, forensic science, the discipline that conducts the majority of investigations into 
cadaver decomposition, currently operates on the assumption that soil microbial metabolism is not associated with the early stages of cadaver breakdown (Evans, 1963). Thus, a significant gap in knowledge exists and is addressed for the first time in this study.

The current experiment was the first to investigate cadaver decomposition in a controlled setting and tested the hypothesis that higher temperature results in greater cadaver decomposition and microbial activity. We were also interested in determining if decomposition rates and temperature effects varied with soil type. Cadaver decomposition was assessed in three contrasting soils from tropical savanna ecosystems in Queensland, Australia, through the measurement of cadaver mass loss. The ecology of these gravesoils was analyzed through the measurement of carbon dioxide-carbon $\left(\mathrm{CO}_{2}-\mathrm{C}\right)$ evolution, microbial biomass carbon (MBC), enzyme activities (protease, phosphodiesterase), and soil $\mathrm{pH}$.

\section{Materials and methods}

\subsection{Cadaver}

Juvenile rat (Rattus rattus) cadavers ( 18 g wet weight) aged 8-10 days were used as organic resource patches. Rats were killed with carbon dioxide immediately prior to burial.

\subsection{Soils}

Three contrasting soil types were collected from Yabulu $\left(19^{\circ} 12^{\prime} \mathrm{S}, 146^{\circ} 36^{\prime} \mathrm{E}\right)$, Pallarenda $\left(19^{\circ} 11^{\prime} \mathrm{S}, 146^{\circ} 46^{\prime} \mathrm{E}\right)$ and Wambiana $\left(20^{\circ} 33^{\prime} \mathrm{S}, 146^{\circ} 08^{\prime} \mathrm{E}\right)$, Queensland, Australia. The soil at Yabulu was a Brown Sodosol (Isbell, 2002) and had a loamy sand texture. The soil at Pallarenda was a Rudosol (Isbell, 2002) and had a sand texture. The soil at Wambiana was a Grey Vertosol (Isbell, 2002) with a medium clay texture. Soil physicochemical properties and methods are presented by Carter et al. (2007a).

\subsection{Experimental design}

Soil (500 g dry weight) was sieved ( $2 \mathrm{~mm})$, weighed into incubation chambers $(21$, high density polyethylene tubs: Crown Scientific, Newstead, Queensland, Australia; Product no. A80WTE+9530C), calibrated to a matric potential of $-0.05 \mathrm{MPa}$, and incubated at $29^{\circ} \mathrm{C}, 22^{\circ} \mathrm{C}$, or $15^{\circ} \mathrm{C}$ for 7 days to equilibrate. This moisture regime was chosen as an approximation to $50 \%$ water-holding capacity. Following equilibration, rats were killed with carbon dioxide $\left(\mathrm{CO}_{2}\right)$, weighed and buried in soil on their right side at a depth of $2.5 \mathrm{~cm}$. Soils associated with a cadaver will be referred to as gravesoil. In control samples soil was disturbed to simulate cadaver burial and account for any effect of soil disturbance. A sequential harvesting regime (Tibbett et al., 2004) was then implemented where cadavers and soils were destructively harvested following 7, 14, 21, or 28 days of incubation. At each harvest event designated cadavers were exhumed along with gravesoil directly surrounding the ca- daver (approximately $50 \mathrm{~g}$ ). The experiment was replicated four times resulting in a total of 288 microcosms.

\subsection{Cadaver mass loss}

Upon exhumation, cadavers were immediately frozen $\left(-20^{\circ} \mathrm{C}\right)$. Once frozen the cadavers were rinsed with distilled water to remove any additional soil, dried with a paper towel and weighed. Harvested soil samples were weighed into sterile culture tubes for further analysis. Soil samples were immediately stored at $-20^{\circ} \mathrm{C}$. To further assess the effect of temperature on mass loss, $Q_{10}$ values were calculated for samples collected on days 7, 14, 21, and 28 .

\subsection{Carbon dioxide-carbon evolution}

Carbon dioxide-carbon evolution was analyzed using the alkali absorption/conductivity method (Rodella and Saboya, 1999). A $30 \mathrm{ml}$ vial (Crown Scientific, Newstead, Queensland, Australia; Product no. 735$)\left(\mathrm{CO}_{2}\right.$ trap) was filled with $20 \mathrm{ml}$ sodium hydroxide $(\mathrm{NaOH})(0.465 \mathrm{M})$ and suspended above the soil surface inside incubation chambers designated for soil sampling after 28 days. The incubation chamber was then sealed. $\mathrm{CO}_{2}$ traps and the air in the incubation chamber headspace were replaced every $24 \mathrm{~h}$. Upon removal from the incubation chamber the electrical conductivity of the $\mathrm{NaOH}$ solution inside the $\mathrm{CO}_{2}$ trap was measured using a Metrohm 660 Conductometer (Herisau, Switzerland). Carbon dioxide evolution was calculated after Rodella and Saboya (1999). To further assess the effect of temperature on C mineralization, $Q_{10}$ values were calculated for $\mathrm{CO}_{2}-\mathrm{C}$ rates on days $7,14,21$, and 28 .

\subsection{Microbial biomass carbon}

Microbial biomass carbon was estimated within $1 \mathrm{~h}$ of harvest using the substrate-induced respiration (SIR) technique (Anderson and Domsch, 1978) with some modifications (Lin and Brookes, 1999). Soil (5 g dry weight) was weighed into $30 \mathrm{ml}$ McCartney bottles and amended with glucose solution $\left(6 \mathrm{mg} \mathrm{g}^{-1}\right.$ soil) in order to calibrate them to $95 \%$ water-holding capacity. Following amendment with glucose solution a $6 \mathrm{ml}$ vial containing $5 \mathrm{ml} \mathrm{NaOH}(0.1 \mathrm{M})$ $\left(\mathrm{CO}_{2}\right.$ trap) was placed on the soil surface and the McCartney bottle was immediately sealed. Samples were then incubated in the dark at $22^{\circ} \mathrm{C}$ for $3 \mathrm{~h}$ or $4 \mathrm{~h}$ based on preliminary experiments (data not shown). After the incubation period $\mathrm{CO}_{2}$ traps were removed and sealed. The $\mathrm{NaOH}$ solution from the $\mathrm{CO}_{2}$ traps was back-titrated with $\mathrm{HCl}(0.1 \mathrm{M})$ into $5 \mathrm{ml} \mathrm{BaCl} 2(1.0 \mathrm{M})$ and 3 drops phenolphthalein as indicator (Rowell, 1994). Microbial biomass carbon was then calculated using the equation in Anderson and Domsch (1978).

\subsection{Enzyme activity}

The activity of casein-hydrolyzing protease and phosphodiesterase (orthophosphodiester phosphohydrolase: EC 3.1.4.1) was assayed. Proteolytic hydrolysis of casein was measured according to Ladd and Butler (1972). Soil phosphodiesterase activity was assayed following Tabatabai (1994). 

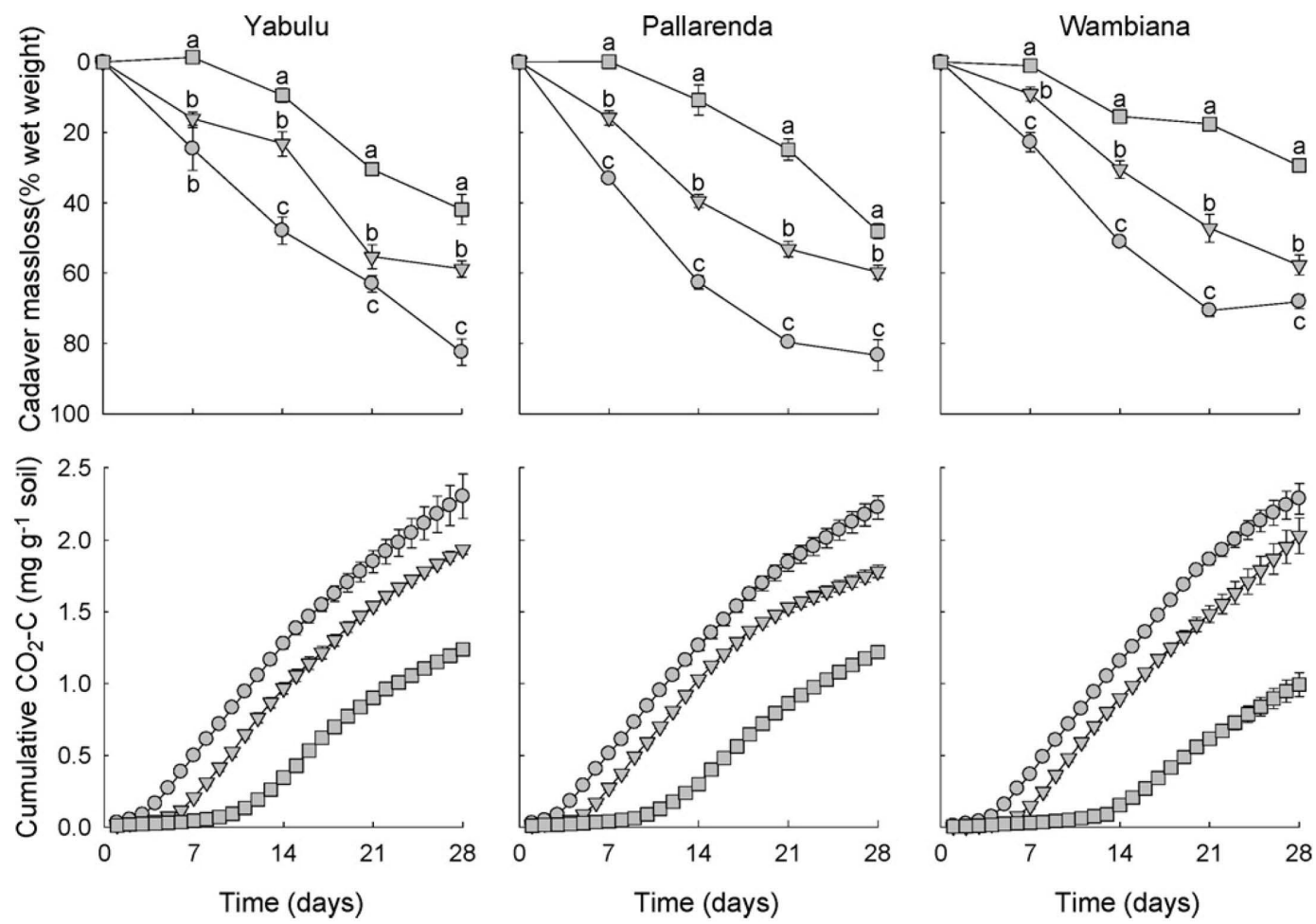

Figure 1. Mass loss (\% wet weight) and cumulative $\mathrm{CO}_{2}-\mathrm{C}$ evolution ( $\mathrm{mg} \mathrm{g}^{-1}$ soil: less control $\mathrm{CO}_{2}-\mathrm{C}$ evolution) following the burial $(2.5 \mathrm{~cm}$ ) of a juvenile rat (Rattus rattus) cadaver in $500 \mathrm{~g}$ (dry weight) sieved (2 mm) soil from Yabulu, Pallarenda, or Wambiana, Queensland, Australia and incubated at $29{ }^{\circ} \mathrm{C}(0), 22{ }^{\circ} \mathrm{C}(\nabla)$, and $15^{\circ} \mathrm{C}(\sqsubset)$. Letters represent a significant $(P<0.05)$ difference between treatments within time. Bars represent standard errors where $n=4$.

\subsection{Statistical analyses}

Descriptive and inferential statistics were generated using Microsoft Excel 2000 and SPSS 11.0.1 (Chicago, USA). Cadaver mass loss, MBC, enzyme activity, and soil $\mathrm{pH}$ data were analyzed using a univariate analysis of variance. Carbon dioxide-carbon evolution data was analyzed using a repeated measures ANOVA following rank transformation.

\section{Results}

\subsection{Cadaver mass loss}

Higher incubation temperatures resulted in more rapid cadaver mass loss (Figure 1). There was also a significant effect of soil type with cadaver mass loss greatest $(P<0.001)$ in Pallarenda soil. Burial resulted in a thinner, more flaccid cadaver by day 28 in all soils at all temperatures. All $Q_{10}$ values were greater than 1.0 with the highest being 7.7 (Table 1). In all treatments, the highest $Q_{10}$ values were observed during the initial 14 days of burial. $Q_{10}$ values then decreased until day 28 . In some cases, $Q_{10}\left(15-22^{\circ} \mathrm{C}\right)$ values were significantly $(P<0.05)$ greater than $Q_{10}\left(22-29^{\circ} \mathrm{C}\right)$ values (Table 1).

\subsection{Carbon dioxide-carbon evolution}

Carbon dioxide-carbon evolution in gravesoil was greater $(P<0.05)$ than in control soil and higher temper- ature resulted in a higher rate of $(P<0.05) \mathrm{CO}_{2}-\mathrm{C}$ evolution (Figure 1). Carbon dioxide-carbon evolution from gravesoils followed a sigmoidal pattern characterized by an early lag phase that, although greater than control soils, represented a relatively slow increase in $\mathrm{CO}_{2}-\mathrm{C}$ evolution. This early lag phase was followed by a period of rapid increase, followed by a period of relatively slower $\mathrm{CO}_{2}-\mathrm{C}$ evolution. This slowing of $\mathrm{CO}_{2}-\mathrm{C}$ evolution was most pronounced in gravesoils incubated at $29^{\circ} \mathrm{C}$ or $22^{\circ} \mathrm{C}$. Carbon dioxide-carbon evolution was not affected by soil type. All $Q_{10}$ values were greater than 1.0 with the highest being 16.2 (Table 1). In all treatments, the highest $Q_{10}$ values were observed during the initial 14 days of burial. $Q_{10}$ values then decreased until day 28 . In some cases, $Q_{10}\left(15-22{ }^{\circ} \mathrm{C}\right)$ values were significantly $(P<0.05)$ greater than $Q_{10}\left(22-29^{\circ} \mathrm{C}\right)$ values (Table 1).

\subsection{Microbial biomass carbon}

MBC in gravesoil was greater $(P<0.05)$ than in control soil (Figure 2). This difference was influenced by temperature, as higher temperature resulted in greater initial increases in MBC as well as earlier peaks in MBC. Thus, peak gravesoil $\mathrm{MBC}$ at $29^{\circ} \mathrm{C}$ was typically observed from days 7 to 14 while incubation at $22^{\circ} \mathrm{C}$ or $15^{\circ} \mathrm{C}$ resulted in peak gravesoil MBC from days 14 to 21 . One exception was Pallarenda gravesoil incubated at $22^{\circ} \mathrm{C}$, where peak $\mathrm{MBC}$ was observed on day 28. A soils effect was also observed as MBC in Yabulu gravesoil was less $(P<0.05)$ than Pallarenda and Wambiana gravesoil. 
Table 1. $Q_{10}$ values for mass loss and carbon dioxide-carbon $\left(\mathrm{CO}_{2}-\mathrm{C}\right)$ evolution following the burial $(2.5 \mathrm{~cm})$ of a juvenile rat $(\mathrm{Rat}$ tus rattus) cadaver in $500 \mathrm{~g}$ (dry weight) sieved $(2 \mathrm{~mm})$ soils from the Yabulu, Pallarenda, or Wambiana, Queensland, Australia incubated at $29^{\circ} \mathrm{C}, 22^{\circ} \mathrm{C}$, or $15^{\circ} \mathrm{C}$

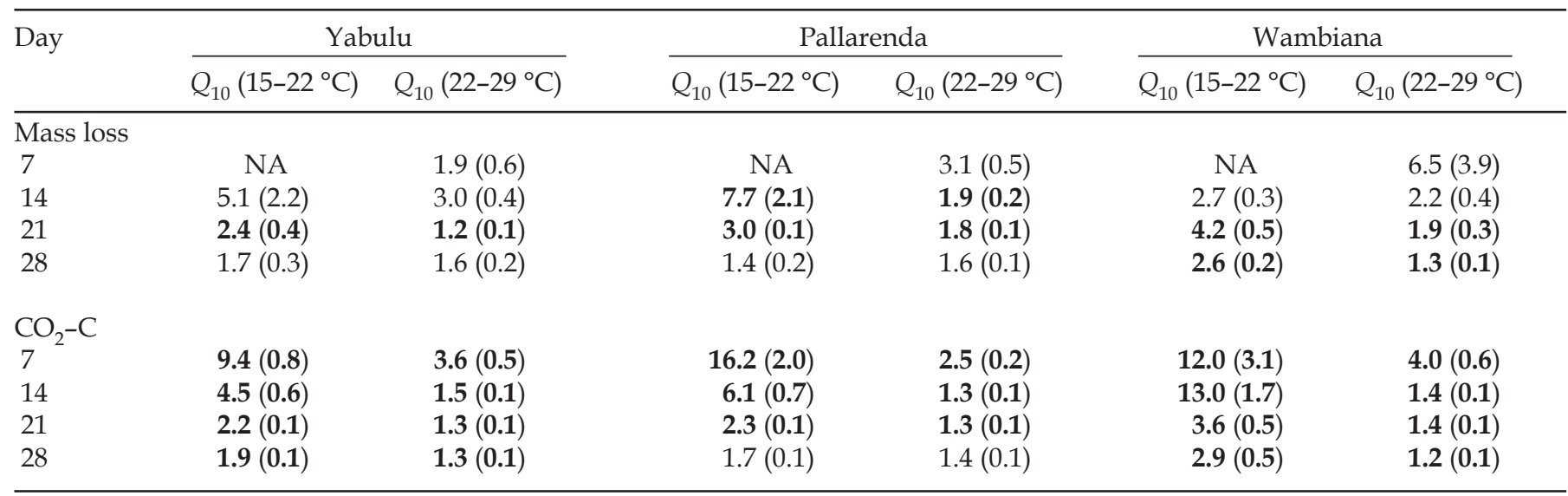

Numbers in parentheses represent standard error where $n=4$. Bold indicates a significant $(P<0.05)$ difference between $Q_{10}$ value within time and soil type. NA indicates inability to calculate $Q_{10}$, where mass loss values were negative (i.e. mass gain was observed).
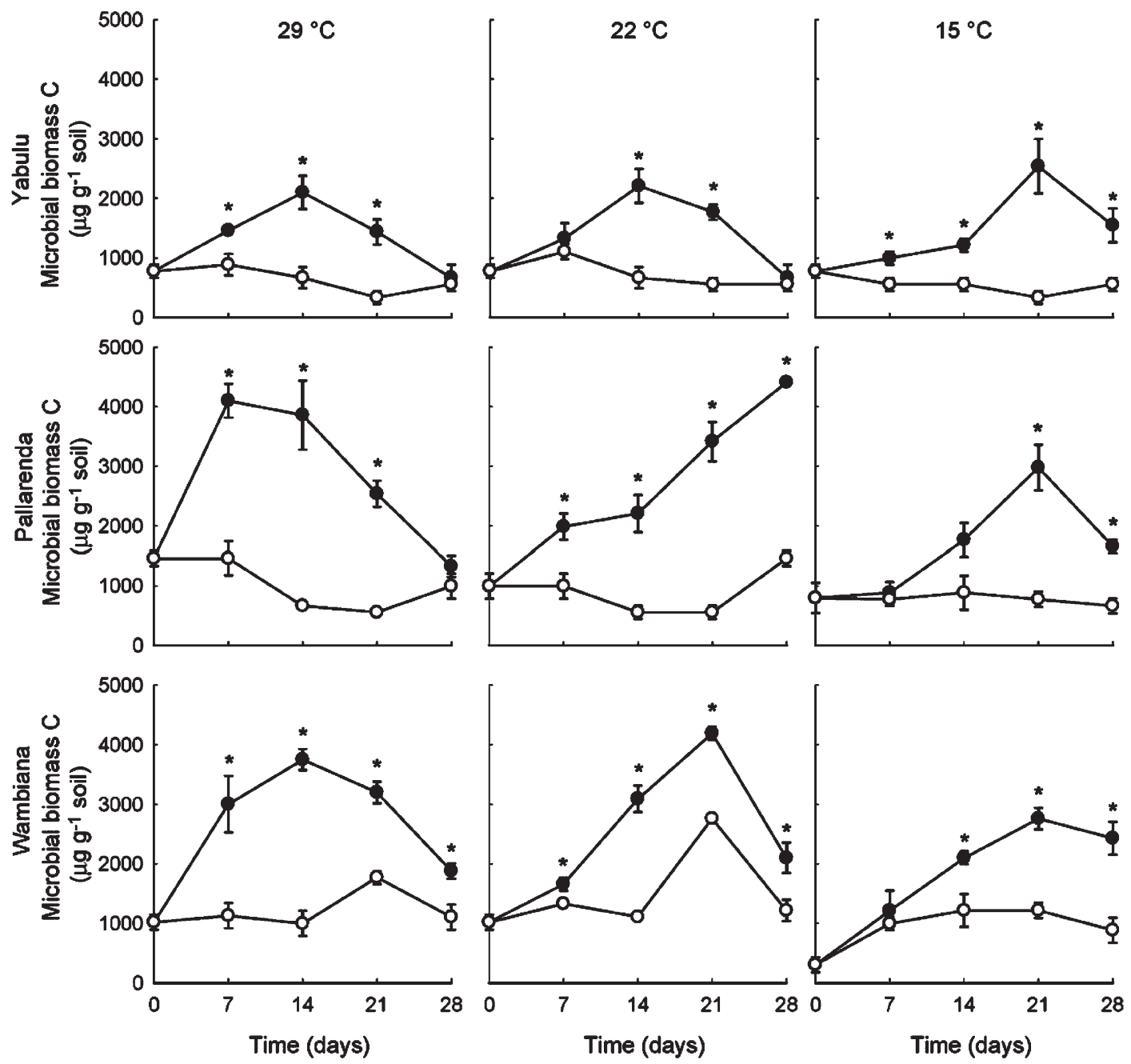

Figure 2. Microbial biomass carbon ( $\mathrm{hg} \mathrm{g}^{-1}$ soil) following the burial $(2.5 \mathrm{~cm})$ of a juvenile rat (Rattus rattus) cadaver $(\bullet)$ and in control (no cadaver: $\circ$ ) samples in $500 \mathrm{~g}$ (dry weight) sieved $(2 \mathrm{~mm}$ ) soils from the Yabulu, Pallarenda, or Wambiana, Queensland, Australia incubated at $29^{\circ} \mathrm{C}, 22{ }^{\circ} \mathrm{C}$, or $15^{\circ} \mathrm{C}$. Bars represent standard errors where $n=4$. *Significant difference between cadaver treatments within time where ${ }^{*} P<0.05$. 

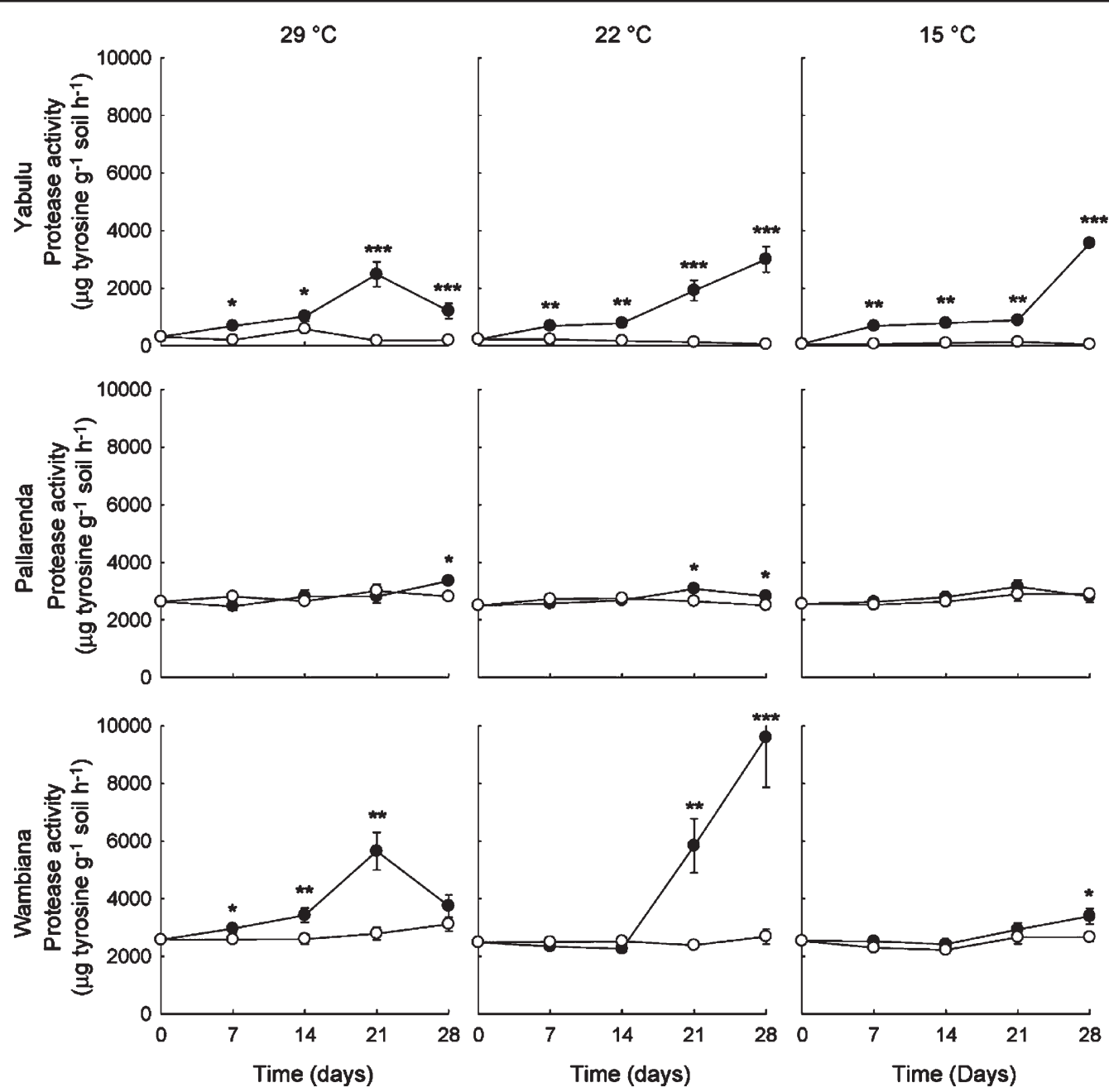

Figure 3. Protease activity $\left(\mu \mathrm{g}\right.$ tyrosine $\left.\mathrm{g}^{-1} \mathrm{soil} \mathrm{h}^{-1}\right)$ following the burial $(2.5 \mathrm{~cm})$ of a juvenile rat $($ Rattus rattus) cadaver $(\bullet)$ and in control (no cadaver: $\circ$ ) samples in $500 \mathrm{~g}$ (dry weight) sieved ( $2 \mathrm{~mm}$ ) soils from the Yabulu, Pallarenda, or Wambiana, Queensland, Australia incubated at $29^{\circ} \mathrm{C}, 22^{\circ} \mathrm{C}$, or $15^{\circ} \mathrm{C}$. Bars represent standard errors where $n=4$. *Significant difference between cadaver treatments within time where ${ }^{*} P<0.05,{ }^{* *} P<0.01$, and ${ }^{* * *} P<0.001$.

Fungal hyphae were observed on the surface of all gravesoils but not observed on any control soils. The presence of fungal hyphae was most common in Wambiana gravesoil but was initially observed in Yabulu gravesoil incubated at $29^{\circ} \mathrm{C}$. There was an apparent relationship between incubation temperature and the appearance of fungal hyphae: hyphae tended to appear earliest at $29^{\circ} \mathrm{C}$ and latest at $15^{\circ} \mathrm{C}$.

\subsection{Enzyme activities}

Similar patterns were observed in protease activity and phosphodiesterase activity (Figures $3 \& 4$ ). Cadaver associated increases in enzyme activities were modified by temperature whereby increases in enzyme activity incubated at $29^{\circ} \mathrm{C}$ took place earlier than at $22^{\circ} \mathrm{C}$, which occurred before an increase at $15^{\circ} \mathrm{C}$. Typically, higher levels of enzyme activity at $29^{\circ} \mathrm{C}$ began by day 7 , increases at $22^{\circ} \mathrm{C}$ began by day 14 , and increases at $15^{\circ} \mathrm{C}$ began by day 14 (Yabulu, Pallarenda) or day 21 (Wambiana). However, no distinguishable pattern of protease activity was observed in Pallarenda soil.
Protease activity in Yabulu, Pallarenda, and Wambiana control soils was approximately $250 \mu \mathrm{g}$ tyrosine $\mathrm{g}^{-1}$ soil h $-1,2750 \mu \mathrm{g}$ tyrosine $\mathrm{g}^{-1} \mathrm{soil} \mathrm{h}^{-1}$, and $2500 \mu \mathrm{g}$ tyrosine $\mathrm{g}^{-1} \mathrm{~s}$ oil $\mathrm{h}^{-1}$, respectively (Figure 3 ). These levels remained constant throughout the incubation. Cadaver burial resulted in greater $(P<0.05)$ protease activity in all gravesoils except Pallarenda soil incubated at $15^{\circ} \mathrm{C}$. Cadaver burial led to protease activities of $2500 \mu \mathrm{g}$ tyrosine $\mathrm{g}^{-1}$ soil h$^{-1}, 2800$ $\mu \mathrm{g}$ tyrosine $\mathrm{g}^{-1}$ soil h$^{-1}$, and $5650 \mu \mathrm{g}$ tyrosine $\mathrm{g}^{-1}$ soil h$^{-1}$ in Yabulu, Pallarenda, and Wambiana gravesoil, respectively. Thus, protease activity was also affected by soil type, as activity in Wambiana gravesoil was greater $(P<0.05)$ than in Yabulu and Pallarenda gravesoil.

Phosphodiesterase activity in Yabulu, Pallarenda, and Wambiana control soils was approximately $10 \mu \mathrm{g} p$-nitroph enol g-1 soil h ${ }^{-1}, 18 \mu \mathrm{g} p$-nitrophenol g ${ }^{-1}$ soil h$^{-1}$, and $60 \mu \mathrm{g}$ $p$-nitrophenol g-1 soil h$^{-1}$, respectively (Figure 4). These levels remained constant throughout the incubation. Cadaver burial resulted in greater $(P<0.05)$ phosphodiesterase activity in all gravesoils. This led to phosphodiesterase activities of $60 \mu \mathrm{g} p$-nitrophenol $\mathrm{g}^{-1} \mathrm{soil} \mathrm{h}^{-1}, 50 \mu \mathrm{g} p$-nitrophenol 

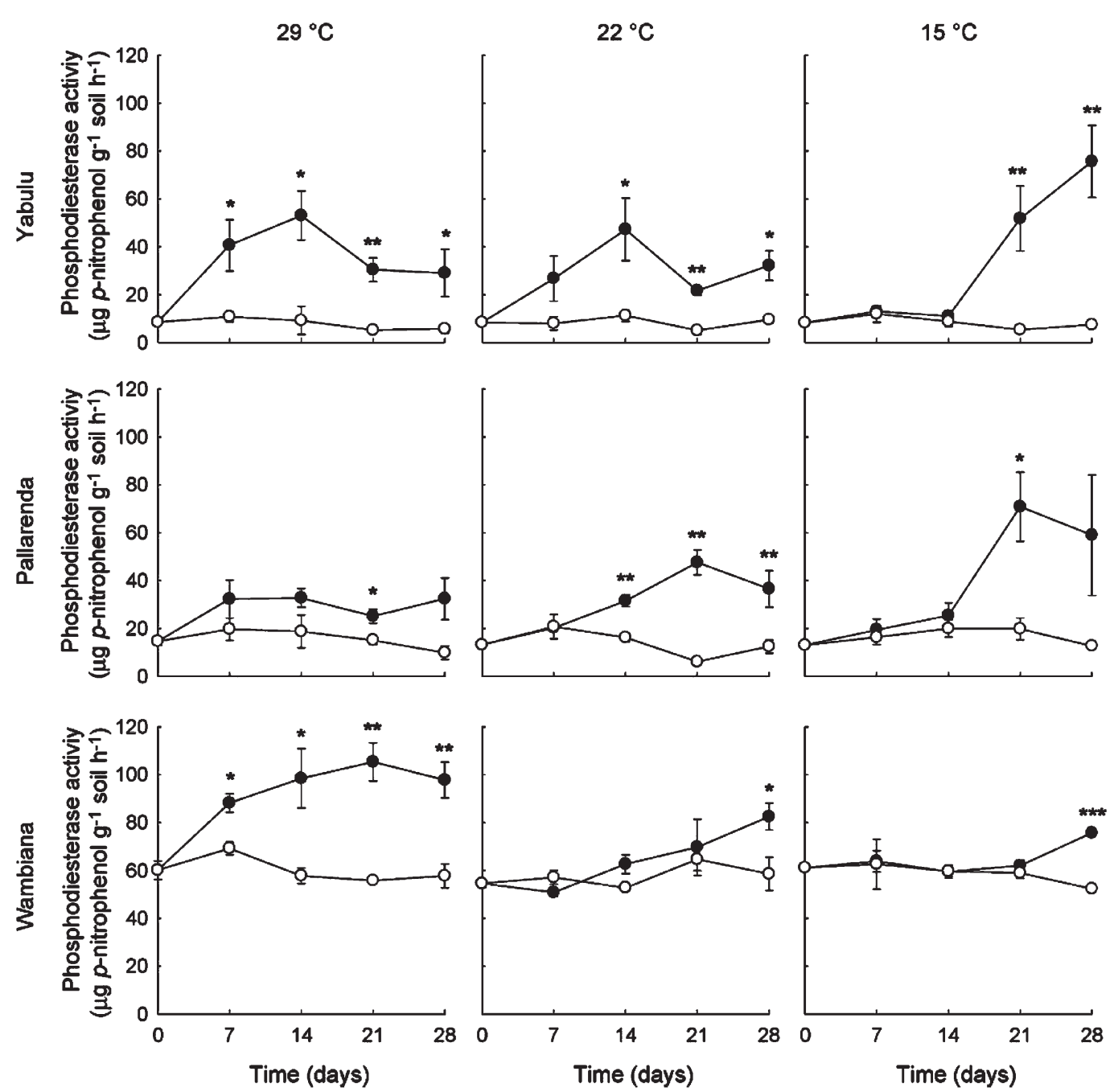

Figure 4. Phosphodiesterase activity ( $\mu \mathrm{g} p$-nitrophenol $\mathrm{g}^{-1}$ soil $\left.\mathrm{h}^{-1}\right)$ following the burial $(2.5 \mathrm{~cm})$ of a juvenile rat (Rattus rattus) cadaver $(\bullet)$ and in control (no cadaver: $\odot$ ) samples in $500 \mathrm{~g}$ (dry weight) sieved $(2 \mathrm{~mm}$ ) soils from the Yabulu, Pallarenda, or Wambiana, Queensland, Australia incubated at $29^{\circ} \mathrm{C}, 22^{\circ} \mathrm{C}$, or $15^{\circ} \mathrm{C}$. Bars represent standard errors where $n=4$. ${ }^{*}$ Significant difference between cadaver treatments within time where ${ }^{*} P<0.05$, ${ }^{* *} P<0.01$, and ${ }^{* *} P<0.001$.

$\mathrm{g}^{-1}$ soil $\mathrm{h}^{-1}$, and $100 \mu \mathrm{g}$ p-nitrophenol $\mathrm{g}^{-1}$ soil $^{-1}$ in Yabulu, Pallarenda, and Wambiana gravesoil, respectively. Phosphodiesterase activity was also affected by soil type, as activity in Wambiana gravesoil was greater $(P<0.05)$ than in Yabulu and Pallarenda gravesoil.

\subsection{Soil $p H$}

Cadaver burial resulted in an increase of $\mathrm{pH}$ to a peak between 8 and 8.1, regardless of basal $\mathrm{pH}$ (Figure 5). This increase was apparently affected by temperature with greater temperature resulting in earlier peaks in $\mathrm{pH}$. In addition, greater decreases in $\mathrm{pH}$ in Yabulu and Pallarenda gravesoil were observed at $29^{\circ} \mathrm{C}$ on day 28 at the end of the incubation.

\section{Discussion}

These data show that cadaver decomposition was more rapid at higher temperature, which corresponded with higher levels of soil microbial activity, microbial biomass, protease activity, and phosphodiesterase activity. A temperature effect was observed where peaks or differences in decomposition that occurred at higher temperature would occur at later sample periods at lower temperature. These findings are consistent with the effect of temperature on the decomposition of skeletal muscle tissue (Ovis aries) (Carter and Tibbett, 2006) and other organic resources such as sewage sludge (Albiach et al., 2000) and pine (Pinus halepensis) needle litter (Coûteaux et al., 2002). The temperature effect on soil respiration, microbial biomass and enzyme activities might indicate that the soil microbial biomass plays a significant role in the decomposition of cadavers following burial in soil.

The current $Q_{10}$ values were similar to $Q_{10}$ values associated with the decomposition of skeletal muscle tissue (Carter and Tibbett, 2006). Similar patterns in relation to temperature range were evident between the two studies with the lower temperature range, $Q_{10}\left(15-22^{\circ} \mathrm{C}\right)$, reporting larger values than $Q_{10}\left(22-29^{\circ} \mathrm{C}\right)$. This is most likely because $15^{\circ} \mathrm{C}$ is outside of the optimal growth range for mi- 

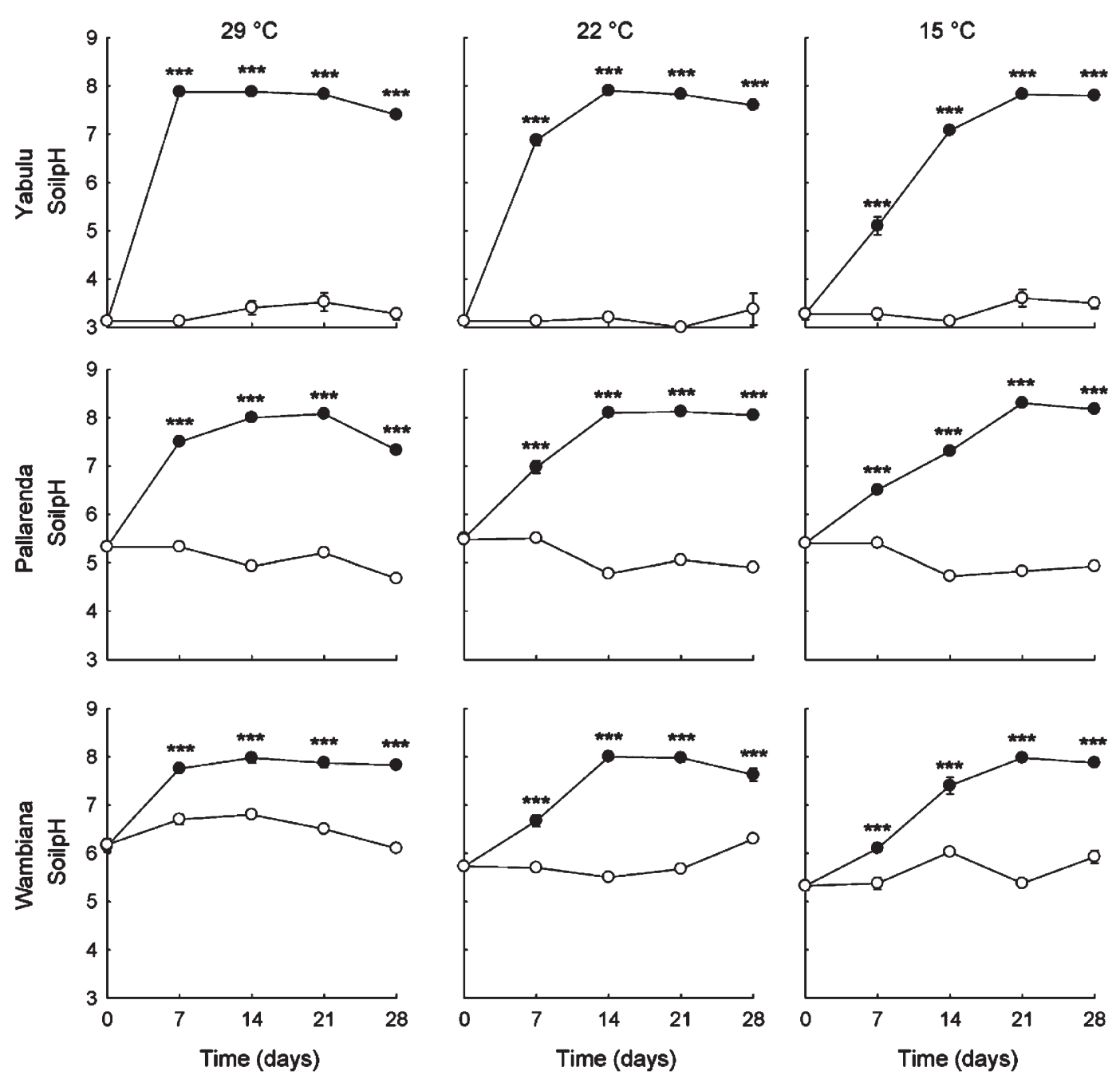

Figure 5. $\mathrm{pH}$ of sieved (2 mm) soils from Yabulu, Pallarenda, or Wambiana, Queensland, Australia following the burial (2.5 cm) of a juvenile rat (Rattus rattus) cadaver $(\bullet)$ and in control (no cadaver: $\circ$ ) samples incubated at $29^{\circ} \mathrm{C}, 22^{\circ} \mathrm{C}$, or $15^{\circ} \mathrm{C}$. Bars represent standard errors where $n=4$. *Significant difference between treatments within time where ${ }^{* *} P<0.001$.

croorganisms in these tropical soils. Some $Q_{10}$ values in the current study far exceed some of those reported previously for mass loss and $\mathrm{CO}_{2}-\mathrm{C}$ respiration. This might reflect large-scale protein utilization, which provides evidence that resource availability plays a crucial role in microbial respiratory response (Liu et al., 2006). That the current $Q_{10}$ values were two to three times higher than those observed with the decomposition of plant litter (e.g. Coûteaux et al., 2002) might demonstrate the significant effect of resource quality on microbial metabolism. As quality (i.e. resource availability) decreases, so do $Q_{10}$ values.

At present, it is not possible to determine whether soilborne or cadaver-borne organisms were the primary mediators of decomposition. It is well-established that a cadaver contains a significant number of enteric microorganisms (Wilson, 2005), which play an important role in cadaver breakdown (Clark et al., 1997; Gill-King, 1997). Investigating this relationship would represent a significant contribution to traditional dogma (Evans, 1963), which states that that aerobic soil and/or dermal microorganisms are not active during the early stages of cadaver decomposition and only play a significant role in cadaver decomposition in the latter stages of decomposition when bone, desiccated tissue and hair represent the primary sources of carbon. Considering that a fresh cadaver is a high quality resource, it seems unlikely that cadaver burial in soil would not trigger the activity of soil microorganisms.

A sigmoidal pattern of cadaver decomposition, observed most clearly here via $\mathrm{CO}_{2}-\mathrm{C}$ evolution, is consistent with several previous cadaver decomposition studies (see Carter et al., 2007b). This sigmoidal pattern comprised three general phases that, in order, comprised a lag phase, a period of rapid decomposition, and a final slowing down of decomposition. The initial lag phase was characterized by initial increases in microbial activity, microbial biomass, protease activity and phosphodiesterase activity. This phase might also have been associated with an initial increase in ammonification, as indicated by an increase in soil $\mathrm{pH}$ (see Hopkins et al., 2000). This period likely represented the initial establishment of the decomposer population. The lag phase was followed by the period of most rapid decomposition, which was characterized by the maintenance of elevated microbial activity, microbial biomass, enzyme activity and $\mathrm{pH}$. This period might represent the proliferation of 
cadaver utilizing, possibly zymogenous, microorganisms. The third period of decomposition was characterized by a slowing of cadaver decomposition and a gradual decrease in microbial activity and microbial biomass. This probably resulted from the depletion of readily available nutrients and a shift in the microbial community from zymogenous to a more autochthonous community.

Perhaps the most compelling evidence of the importance of temperature on cadaver decomposition, at least from a practical (forensic) perspective, is that the final phase of decomposition was only observed at $29^{\circ} \mathrm{C}$ and $22^{\circ} \mathrm{C}$ and not at $15^{\circ} \mathrm{C}$, which serves to highlight the important effect of temperature on cadaver breakdown and resource availability. Interestingly, peak protease activity was associated with late phase decomposition. Similar patterns have been observed during the decomposition of leaf litter (Dilly and Munch, 1996; Nannipieri et al., 1983) and might be due to the release of labile organic materials upon the death of the microbial biomass (Nunan et al., 2000). This might signal a second change in microbial community structure: the proliferation of zymogenous microorganisms in response to the introduction of dead microbial cells (e.g. Nunan et al., 2000). This late peak in protease activity may also have implications for the study of prion protein degradation in soil (see Rapp et al., 2006) particularly given the general lack of temperature responsiveness, most notable in the Pallarenda soil.

Several effects of soil type were observed during cadaver decomposition. First, cadaver mass loss was greatest in Pallarenda soil, which is consistent with other observations of cadaver decomposition in sandy soils (Fiedler et al., 2004,; Forbes et al., 2005). Rapid mass loss (fresh weight) was probably due to rapid desiccation resulting from a greater rate of gas diffusion in a coarse-textured soil. Differences in protease activity between soils might be due to the relatively high basal level of $\mathrm{N}$ in Wambiana soil, which could result in little need for the breakdown of proteinaceous materials by soil microorganisms. In contrast, phosphodiesterase activity in Wambiana gravesoil was greater $(P<0.05)$ than in Yabulu and Pallarenda gravesoil. The reason for this is unclear but may reflect great microbial demand for $\mathrm{P}$ in a potentially $\mathrm{P}$ fixing (clay) soil (see Carter et al., 2007a, and discussion in Tibbett, 2002), or alternatively may simply reflect different microbial community function between the soils.

Soil type, however, did not affect the dynamics of gravesoil $\mathrm{pH}$ but did affect the magnitude of the change. In each case $\mathrm{pH}$ rose to approximately $\mathrm{pH} 8$, a remarkable change of almost $5 \mathrm{pH}$ units in 7 days for Yabulu but closer to $2 \mathrm{pH}$ units for Wambiana. The increase of $\mathrm{pH}$ following cadaver burial has been attributed to the accumulation of ammonium (Hopkins et al., 2000) and observed in association with human (Vass et al., 1992), dog (Canis familiaris) (Reed, 1958), and pig (Sus scrofa) (Hopkins et al., 2000) cadavers as well as skeletal muscle tissue from lamb (O. aries) (Carter and Tibbett, 2006). The decrease in $\mathrm{pH}$ observed in some gravesoils incubated at $29^{\circ} \mathrm{C}$ or $22^{\circ} \mathrm{C}$ could be the result of soil returning to its basal $\mathrm{pH}$ due to the microbial utilization of base cations. This might reflect more complete decomposition that has been observed in association with the decomposition of human (Vass et al., 1992) and bi- son (Bos bison) (Towne, 2000) cadavers over periods longer than 28 days.

The current study demonstrates that microbial activity is a major contributor to cadaver decomposition in soil and shows that the persistence of a cadaver in soil can be influenced by temperature and soil type. These findings contradict the long-standing assumption that soil type has little effect on cadaver breakdown (Mant, 1950) but does not yet completely address the assumption that soil microorganisms do not participate in the early stages of cadaver decomposition (Evans, 1963). This new insight has implications for applied soil ecology, particularly when used in forensic science. Soils are typically used by forensic science to link objects and persons with crime scenes. However, many cadaver decomposition studies have shown that processes in soil can help to locate clandestine graves (Carter et al., 2008) and estimate time since death (Vass et al., 1992). The current laboratory conditions have shown that different temperature-based models for predicting cadaver decomposition might differ between soils. The precision of these applications will only be improved through the investigation of cadaver decomposition in field and laboratory conditions.

Acknowledgments - We thank Scott Blyth for the breeding of rats, we thank Joe Holtum, Mike Whiting, Chris Stokes, Peter O'Reagain, Colin Adams for access to sites for soil collection, and we are grateful to Joe Holtum for access to the incubation chambers used in the study. We also thank the reviewers for their constructive comments regarding this manuscript.

\section{References}

Albiach et al., $2000 \varangle$ R. Albiach, R. Canet, F. Pomares, and F. Ingelmo, Microbial biomass content and enzymatic activities after the application of organic amendments to a horticultural soil, Bioresour. Technol. 75 (2000), pp. 43-48.

Anderson and Domsch, $1978<$ J. P. E. Anderson and K. H. Domsch, A physiological method for the quantitative measurement of microbial biomass in soils, Soil Biol. Biochem. 10 (1978), pp. 215-221.

Carter and Tibbett, $2006 \varangle$ D. O. Carter and M. Tibbett, Microbial decomposition of skeletal muscle tissue (Ovis aries) in a sandy loam soil at different temperatures, Soil Biol. Biochem. 38 (2006), pp. 1139-1145.

Carter et al., 2007a 4 D. O. Carter, D. Yellowlees, and M. Tibbett, Autoclaving can kill soil microbes yet enzymes can remain active, Pedobiologia 51 (2007), pp. 295-299.

Carter et al., 2007b $\varangle$ D. O. Carter, D. Yellowlees, and M. Tibbett, Cadaver decomposition in terrestrial ecosystems, Naturwissenschaften 94 (2007), pp. 12-24.

Carter et al., $2008<$ D. O. Carter, D. Yellowlees, and M. Tibbett, Using ninhydrin to detect gravesoil, J. Forensic Sci 53 (2008), pp. 397-400.

Clark et al., $1997 \varangle$ M. A. Clark, M. B. Worrell, and J. E. Pless, Postmortem changes in soft tissue. In: W. D. Haglund and M. H. Sorg, Editors, Forensic Taphonomy: The Postmortem 
Fate of Human Remains, CRC Press, Boca Raton, FL, USA (1997), pp. 151-164.

Coûteaux et al., 20024 M.-M. Coûteaux, A. Aloui, and C. Kurz-Besson, Pinus halepensis litter decomposition in laboratory microcosms as influenced by temperature and a millipede, Glomeris marginata, Appl. Soil Ecol. 20 (2002), pp. 85-96.

Dilly and Munch, 19964 O. Dilly and J.-C. Munch, Microbial biomass content, basal respiration and enzyme activities during the course of decomposition of leaf litter in a black alder (Alnus glutinosa (L.) Gaertn.) forest, Soil Biol. Biochem. 28 (1996), pp. 1073-7081.

Evans, $1963<$ W. E. D. Evans, The Chemistry of Death, Charles C. Thomas, Springfield, IL, USA (1963).

Fiedler et al., $2004 \triangleleft$ S. Fiedler, K. Schneckenberg and M. Graw, Characterization of soils containing adipocere, Arch. Environ. Contam. Toxicol. 47 (2004), pp. 561-568.

Forbes et al., 20054 S. L. Forbes, B. B. Dent, and B. H. Stuart, The effect of soil type on adipocere formation, Forensic Sci. Int. 154 (2005), pp. 35-43.

France et al., $1992 \triangleleft$ D. L. France, T. J. Griffin, J. G. Swanburg, J. W. Lindemann, G. C. Davenport, V. Trammell, C. T. Travis, B. Kondratieff, A. Nelson, K. Castellano, and D. Hopkins, A multidisciplinary approach to the detection of clandestine graves, J. Forensic Sci. 37 (1992), pp. 1445-1458.

Gill-King, $19974 \mathrm{H}$. Gill-King, Chemical and ultrastructural aspects of decomposition. In: W. D. Haglund and M. H. Sorg, Editors, Forensic Taphonomy: The Postmortem Fate of Human Remains, CRC Press, Boca Raton, FL, USA (1997), pp. 93-108.

Hopkins et al., $2000<$ D. W. Hopkins, P. E. J. Wiltshire, and B. D. Turner, Microbial characteristics of soils from graves: an investigation at the interface of soil microbiology and forensic science, Appl. Soil Ecol. 14 (2000), pp. 283-288.

Isbell, 20024 R. F. Isbell, The Australian Soil Classification, CSIRO Publishing, Collingwood (2002).

Ladd and Butler, $1972<$ J. N. Ladd and J. H. A. Butler, Shortterm assays of soil proteolytic enzyme activities using proteins and dipeptide derivatives as substrates, Soil Biol. Biochem. 4 (1972), pp. 19-30.

Lin and Brookes, $1999 \triangleleft$ Q. Lin and P. C. Brookes, An evaluation of the substrate-induced respiration method, Soil Biol. Biochem. 31 (1999), pp. 1969-1983.

Liu et al., 2006 ४ H. S. Liu, L. H. Li, X. G. Han, J. H. Huang, J. X. Sun, and H. Y. Wang, Respiratory substrate availability plays a crucial role in the response of soil respiration to environmental factors, Appl. Soil Ecol. 32 (2006), pp. 284-292.

Mant, 1950 A. K. Mant, A study in Exhumation Data. Unpublished MD Thesis. London University, London, 1950.

Megyesi et al., 20054 M. S. Megyesi, S. P. Nawrocki, and N. H. Haskell, Using accumulated degree-days to estimate the postmortem interval from decomposed human remains, $J$. Forensic Sci. 50 (2005), pp. 618-626.
Morovic-Budak, 19654 A. Morovic-Budak, Experiences in the process of putrefaction in corpses buried in earth, $\mathrm{Med}$. Sci. Law 5 (1965), pp. 40-43.

Nannipieri et al., $1983 \triangleleft$ P. Nannipieri, L. Muccini, and C. Ciardi, Microbial biomass and enzyme activities: production and persistence, Soil Biol. Biochem. 15 (1983), pp. 679-685.

Nunan et al., $2000 \triangleleft$ N. Nunan, M. A. Morgan, J. Scott, and M. Herlihy, Temporal changes in nitrogen mineralisation, microbial biomass, respiration and protease activity in a clay loam soil under ambient temperature, Biol. Environ. 100B (2000), pp. 107-114.

Paul and Clark, 1996 E. A. Paul and F. E. Clark, Soil Microbiology and Biochemistry (2nd ed.), Academic Press, San Diego, CA (1996).

Rapp et al., $2006<$ D. Rapp, P. Potier, L. Jocteur-Monrozier, and A. Richaume, Prion degradation in soil: possible role of microbial enzymes stimulated by the decomposition of buried carcasses, Environ. Sci. Technol. 40 (2006), pp. 6324-6329.

Reed, $1958 \triangleleft$ H. B. Reed, A study of dog carcass communities in Tennessee, with special reference to the insects, $A m$. Midl. Nat. 59 (1958), pp. 213-245.

Rodella and Saboya, 1999 A. A. Rodella and L. V. Saboya, Calibration of conductimetric determination of carbon dioxide, Soil Biol. Biochem. 31 (1999), pp. 2059-2060.

Rowell, $1994 \varangle$ D. L. Rowell, Soil Science: Methods and Applications, Longman Group UK Limited, Harlow, UK (1994).

Swift et al., $1979 \triangleleft$ M. J. Swift, O. W. Heal, and J. M. Anderson, Decomposition in Terrestrial Ecosystems, Blackwell Scientific, Oxford (1979).

Tabatabai, $1994 \triangleleft$ M. A. Tabatabai, Soil enzymes. In: R. W. Weaver et al., eds., Methods of Soil Analysis. Part 2. Microbiological and Biochemical Properties, SSSA, Madison, WI (1994), pp. 775-833.

Tibbett, $20024 \mathrm{M}$. Tibbett, Considerations on the use of the $p$-nitrophenol phosphomonoesterase assay in the study of the phosphorus nutrition of soil borne fungi, Microbiol. Res. 157 (2002), pp. 221-231.

Tibbett et al., $2004 \triangleleft$ M. Tibbett, D. O. Carter, T. Haslam, R. Major, and R. Haslam, A laboratory incubation method for determining the rate of microbiological degradation of skeletal muscle tissue in soil, J. Forensic Sci. 49 (2004), pp. $560-565$.

Towne, $2000 \triangle$ E. G. Towne, Prairie vegetation and soil nutrient responses to ungulate carcasses, Oecologia 122 (2000), pp. 232-239.

Vass et al., 1992 A. A. Vass, W. M. Bass, J. D. Wolt, J. E. Foss, and J. T. Ammons, Time since death determinations of human cadavers using soil solution, J. Forensic Sci. 37 (1992), pp. 1236-1253.

Wilson, $20054 \mathrm{M}$. Wilson, Microbial Inhabitants of Humans, Cambridge University Press, Cambridge, UK (2005). 